\title{
Biosaintifika
}

Journal of Biology \& Biology Education

\section{Impact of Distance from the Forest Edge on The Wild Bee Diversity on the Northern Slope of Mount Slamet}

\author{
${ }^{\square}$ Imam Widhiono, Eming Sudiana
}

DOI: 10.15294/biosaintifika.v8i2.5058

Faculty of Biology, Jenderal Soedirman University, Indonesia

History Article

Received 13 February 2016

Approved 16 June 2016

Published 18 September 2016

\section{Keywords:}

abundance; diversity; distance; forest edges; species; wild bees

\begin{abstract}
In agricultural landscape in northern slope of Mount Slamet, diversity of wild bee species as pollinator depend on forested habitats. This study aimed to assess the effects of distance from the forest edge on the diversity of wild bees on strawberry and tomato crops. This study was conducted from July 2014 to October 2014. The experimental fields contained tomato and strawberry with a total area of 4 ha (2 ha each) and divided into five plots based on distance from the forest edge $(0,50,100$, 150 , and $200 \mathrm{~m}$ ). Wild bee was catched with kite netting in $7.00-9.00$ in ten consecutive days. Wild bee diversity differed according to distance from the forest edge, the highest value was at $0 \mathrm{~m}$ for strawberry plots $\left(\mathrm{H}^{\prime}=2.008, \mathrm{E}=0.72\right.$ and Chaol= 16) and for tomato plots, the highest diversity was at $50 \mathrm{~m}$ from the forest edge $\left(\mathrm{H}^{\prime}=\right.$ $2.298, \mathrm{E}=0.95$ and Chao1 $=11$ ) and the lowest was at $200 \mathrm{~m}$ in both plots. Wild bee species richness and abundance decreased with distance, resulting in the minimum diversity and abundance of wild bee at $200 \mathrm{~m}$ from forest edge in both crops.
\end{abstract}

\section{How to Cite}

Widhiono, I., \& Sudiana, E. (2016). Impact of Distance from the Forest Edge on The Wild Bee Diversity on the Northern Slope of Mount Slamet. Biosaintifika: Journal of Biology \& Biology Education, 8(2), 148-154.

(C) 2016 Semarang State University
Correspondence Author:

J1. Dr. Soeparno No 63 Purwokerto 53122

E-mail: imamwidhiono@yahoo.com
p-ISSN 2085-191X

e-ISSN 2338-7610 


\section{INTRODUCTION}

Since 1998, the forest areas on the northern slopes of Mount Slamet have been developed as agricultural areas (Perhutani, 2000), which have resulted in landscape fragmentation by reducing the amount of natural and semi-natural habitats. Natural and semi-natural habitats provide essential resources for wild bees, which act as crop pollinators in agricultural areas. The major agricultural commodities in this region are strawberries and tomatoes; pollination of both crops is dependent on the presence of wild bees in forested habitats. Wild bees (Hymenoptera: Apoidea) are considered the most important group of insect pollinators in agricultural landscapes. Habitat loss and fragmentation leads to changes in wild bee abundance and species richness, which may affect crop pollination.

Habitat loss and isolation due to agricultural intensification represent major threats to insect pollinator diversity because ecologically valuable wild bee habitats remaining in agricultural landscapes tend to be confined to a relatively small proportion of semi-natural habitats. Forest edges, as the remaining semi-natural habitat in these areas, provide essential resources for pollinators within agricultural landscapes and may help to maintain pollination services in agroecosystems. Recent research by Widhiono \& Sudiana (2015) found that forest edges have abundant flowering wild plant species, which are food sources for wild bees. Therefore, the forest areas on the northern slopes of Mount Slamet play an important role by harboring wild bees as pollinators for adjacent farmland. Forest edge areas within agricultural landscapes often provide habitat for wild bee species, from which they forage on flowering crops in agricultural fields. Several studies have shown the importance of natural or semi-natural habitats, such as forest edges, in sustaining pollinator populations close to fruit crops (Carvalheiro et al., 2010).

The optimal foraging theory predicts that the mean richness level of wild bee pollinators decreases with distance from the forest edge (Cresswell et al., 2000), because a majority of wild bee pollinators are central place foragers with fixed nest sites (such as in the soil, plant stems, or trees) within the forest edges. In tropical ecosystems in Asia, wild bee abundance and species richness are affected by distance from the forest edge, and the abundance of insect pollinators often declines with distance from the forest edge (Klein et al., 2003). Wild bee abundance and richness decreases with distance from the fo- rest edge, resulting in a decline in the mean levels of flower-visitor richness and visitation rate in croplands around forest edges. In the study area, strawberries and tomatoes are planted around forest edges, so distance from the forest edge affects the diversity and abundance of wild bee pollinators. This study aimed to assess the effect of distance from the forest edge on the diversity and abundance of wild bees on strawberry and tomato crops. The results will facilitate the development of a strategy for insect pollinator conservation in agricultural areas.

\section{METHODS}

\section{Study site}

This study was conducted from July 2014 to October 2014 on the northern slope of Mount Slamet, Central Java, in Serang village (altitude $\pm 1100 \mathrm{~m}$ asl (above sea levels), which is located at $7^{\circ} 14^{\prime} 21^{\prime \prime} \mathrm{S}$ and $109^{\circ} 17^{\prime} 37.42^{\prime \prime} \mathrm{E}$. The experimental fields contained tomato (Lycopersicum esculentum) and strawberry (Fragaria $x$ annanasa) crops adjacent to the forest edge, with a total area of 4 ha (2 ha each). Each agricultural field was divided into five plots based on distance from the forest edge $(0,50,100,150$, and $200 \mathrm{~m})$.

\section{Sampling Methods}

Wild bee sampling was performed in every 40 plants in each plot using the scan method i.e., observing wild bees visiting and pollinating flowers. Sampling was conducted in the morning (7.00-9.00 AM) every week and replicate five times periods. For identification, wild bees were collected using kite netting. Furtehermore, all wild bee specimens sned to LIPI Bogor to species identification.

\section{Data Analysis}

The species richness and abundances of wild bees recorded in the five plots were analyzed. A general linear model was applied using the SPSS ver. 18.0 software. The dependent variables were wild bee species number and abundance, and the categorical variable was the distance from the forest edge $(0,50,100,150$, and $200 \mathrm{~m})$. Raw data from the field were used to reveal species richness with estimators Chao 1, species diversity (Shannon-Weiner index), Evenness (E), and relative abundance of different species in a sampling site (Magurran, 2003). Comparisons of species composition according to the distance from the forest edge were performed using single linkage cluster analysis based on Bray-Curtis similarity (McAleece et al., 1997). All diversity parameters 
were analyzed using the Biodiversity Pro software (McAleece et al., 1997).

\section{RESULTS AND DISCUSSION}

We recorded 680 wild bees representing 15 species or species groups in 12 genera in strawberry plots, and 379 individuals representing 11 species in tomato plots. The most abundant and widespread bee species in the strawberry plots were Trigona laeviceps (36.3\%), Apis cerana (28.6\%), and Rophalidia romandi (12.4\%) while the most abundant species in tomato plots were A.cerana (18.7\%), Megachille relativa (12.95\%), and Amegilla cingulata $(12.1 \%)$. (Tabel 1). The differences of species dominance between two crops were due to differences of flower characters. Flower visitors of strawberries dominated by small bees, while tomatoes flower dominated by buzzing bees. One of the features of the tomatoes flowers is the sporicidal opening of its anthers which requires the agitation of the flowers by the presence of pollinators that vibrate their indirect flight muscles for the release of pollen grains. Teppner (2005), observed that Bombus and Lasioglossum, can be good pollinators of the flowers by vibrating their anthers easily. Harter et al., (2002) note that some families of bees from that perform buzz pollination and dominate at tomatoes fields are Andrenidae, Apidae, Colletidae, Halictidae, and Megachilidae.
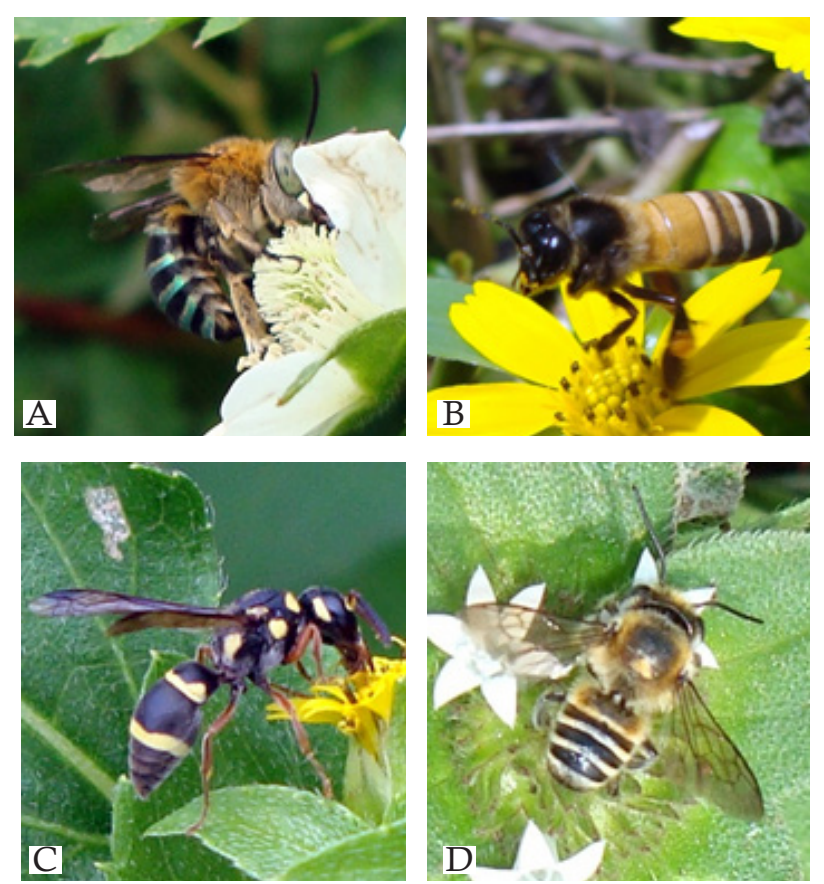
(Figure 2). las and Chao, 2013).

Figure 1. Wild bee species found in sampling area ie. A. Amegilla cingulata, B. Apis cerana, C. Ropalidia romandi, D. Megachlie relativa

Wild bee population and wild bee species richness according to the distance from the forest edge in strawberry and tomato plots, showed that the highest species richness was at $0 \mathrm{~m}$ and the lowest at $200 \mathrm{~m}$ from the forest edge for both crops

The species diversity indices ( $\mathrm{H}^{\prime}$, Evenness E) and species estimator (Chao 1) differed according to the distance from the forest edge. The highest value was at $0 \mathrm{~m}$ in the strawberry plots $\left(\mathrm{H}^{\prime}=2.008, \mathrm{E}=0.72\right.$ and $\left.\mathrm{Chao1}=16\right)$ and the lowest at $200 \mathrm{~m}\left(\mathrm{H}^{\prime}=1.708, \mathrm{E}=0.77\right.$ and Chao1= 9). In tomato plots, the highest diversity was at $50 \mathrm{~m}$ from the forest edge $\left(\mathrm{H}^{\prime}=2.298, \mathrm{E}=0.95\right.$ and Chao1 $=11)$ and the lowest was at $200 \mathrm{~m}\left(\mathrm{H}^{\prime}\right.$ $=2.156, \mathrm{E}=0.98$ and Chao1=9) $($ Table 2).From data analysis showed that Chao1, (the simplest nonparametric species richness estimator), not significantly different with the result. This result indicated that the sample in both plantations has the full assemblage of species, including those species not detected in the set of samples (Nicho-

The data suggest a relationship between the distance from the forest edge and the likelihood of thediversity of wild bees in strawberry and tomato fields. A Kruskal-Wallis test showed that between the distance from the forest has significant differences $(p<0.05)$ on wild bee populations and wild bee species richness in both strawberry and tomato plots. Bee species richness was sig- 


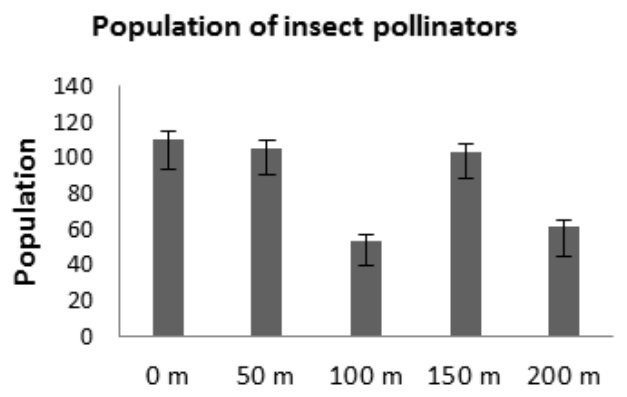

Planting distance from the forest

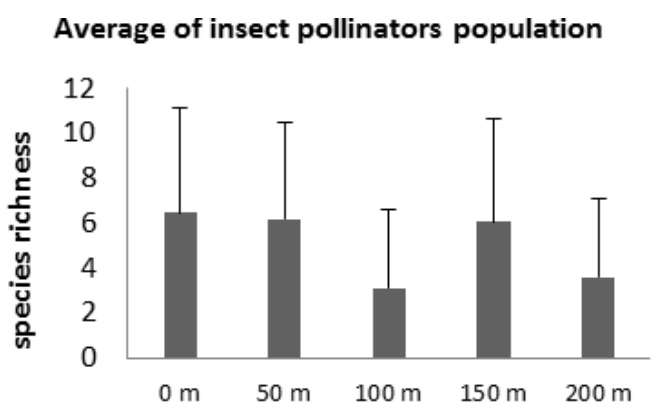

Planting distance from the forest

A

Figure 2.Wild bee population (A) and wild bee species richness (B) according to the distance from the forest edge in strawberry and tomato plots.

Table 1. Wild bee abundance in strawberry and tomato plots according to the distance from the forest edge.

\begin{tabular}{lcccccccccc}
\hline & \multicolumn{1}{c}{ Strawberry } \\
\cline { 2 - 11 } Insect species & \multicolumn{1}{c}{ Diatance from forest edges } \\
\cline { 2 - 13 } & $0 \mathrm{~m}$ & $50 \mathrm{~m}$ & $100 \mathrm{~m}$ & $150 \mathrm{~m}$ & $200 \mathrm{~m}$ & $0 \mathrm{~m}$ & $50 \mathrm{~m}$ & $100 \mathrm{~m}$ & $150 \mathrm{~m}$ & $200 \mathrm{~m}$ \\
\hline A. cerana & 46 & 48 & 29 & 41 & 31 & 22 & 7 & 30 & 5 & 7 \\
A.dorsata & 6 & 6 & 0 & 0 & 0 & 0 & 0 & 0 & 0 & 0 \\
T. laeviceps & 59 & 53 & 50 & 45 & 40 & 0 & 0 & 0 & 0 & 0 \\
R.romandi & 7 & 7 & 7 & 7 & 7 & 7 & 7 & 7 & 7 & 7 \\
R. fasciata & 5 & 5 & 5 & 5 & 5 & 5 & 5 & 5 & 5 & 5 \\
M.relativa & 10 & 7 & 8 & 4 & 6 & 11 & 11 & 11 & 10 & 6 \\
A.cingulata & 6 & 6 & 6 & 6 & 3 & 12 & 14 & 6 & 6 & 6 \\
A.zonata & 7 & 7 & 7 & 5 & 6 & 13 & 13 & 7 & 7 & 6 \\
X.latipes & 1 & 0 & 0 & 0 & 0 & 13 & 5 & 1 & 1 & 0 \\
X. virginica & 1 & 0 & 0 & 0 & 0 & 0 & 0 & 0 & 0 & 0 \\
Polistes sp & 3 & 3 & 0 & 0 & 0 & 5 & 3 & 3 & 3 & 3 \\
Nomia sp. & 4 & 0 & 4 & 4 & 0 & 4 & 4 & 4 & 4 & 4 \\
L.malachurum & 3 & 3 & 3 & 3 & 3 & 7 & 5 & 3 & 3 & 0 \\
D.campaniforme & 9 & 6 & 7 & 4 & 4 & 1 & 9 & 6 & 9 & 9 \\
P.politus & 3 & 0 & 3 & 1 & 0 & 0 & 0 & 0 & 0 & 0 \\
Insect & 170 & 151 & 129 & 125 & 105 & 100 & 83 & 83 & 60 & 53 \\
abundance & 11.33 & 10.07 & 8.60 & 8.33 & 7.00 & 9.09 & 7.55 & 7.55 & 5.45 & 4.82 \\
Mean & 17.09 & 16.67 & 13.46 & 14.29 & 11.97 & 5.86 & 3.72 & 7.90 & 2.70 & 2.86 \\
STDev & & & & & & & & & &
\end{tabular}

nificantly affected by distance to the main habitat. Distance from the forest edge was associated with decreased wild bee abundance and richness. Distance also greatly affected assemblage composition. Our results suggest that distance strongly determines the spatial distribution of bees in the study area. Distance from the forest edge had a significant effect; (Spearman's correlation; $r^{2}=$
$0.96, p<0.05$ in strawberry plots with equations $Y$ $=167.200-0.312 \times$ and $r^{2}=0.75, p<0.05$ in tomato plots with equations $\mathrm{Y}=99.200-0.234 \mathrm{x}$ ), the same effects has also showed on species richness $\mathrm{r}^{2}=0.96, \mathrm{p}<0.05$ with equations $\mathrm{Y}=13.800$ $0.024 \mathrm{x}$ in strawberry plots and $\mathrm{r}^{2}=0.52, \mathrm{p}<0.05$ with equations $\mathrm{Y}=11.400-0.008 \mathrm{x}$ in tomatoes plots), this mean that bee abundance declined 
Table 2. Species richness and diversity parameters in strawberry and tomato plots according to the distance from the forest edge

\begin{tabular}{lcccccccccc}
\hline \multicolumn{1}{c}{ Parameters } & \multicolumn{1}{c}{ Strawberry } \\
\hline & $0 \mathrm{~m}$ & $50 \mathrm{~m}$ & $100 \mathrm{~m}$ & $150 \mathrm{~m}$ & $200 \mathrm{~m}$ & $0 \mathrm{~m}$ & $50 \mathrm{~m}$ & $100 \mathrm{~m}$ & $150 \mathrm{~m}$ & $200 \mathrm{~m}$ \\
\hline Species richness & 15 & 11 & 11 & 11 & 9 & 11 & 11 & 11 & 11 & 9 \\
STDev species & 0.00 & 0.46 & 0.46 & 0.46 & 0.51 & 0.00 & 0.00 & 0.00 & 0.00 & 0.40 \\
Shannon H' & 2.008 & 1.812 & 1.901 & 1.757 & 1.708 & 2.207 & 2.290 & 2.041 & 2.27 & 2.156 \\
Evenness & 0.742 & 0.756 & 0.793 & 0.733 & 0.777 & 0.921 & 0.955 & 0.851 & 0.95 & 0.981 \\
Chao-1 & 16 & 11 & 11 & 11 & 9 & 11 & 11 & 11 & 11 & 9 \\
\hline
\end{tabular}

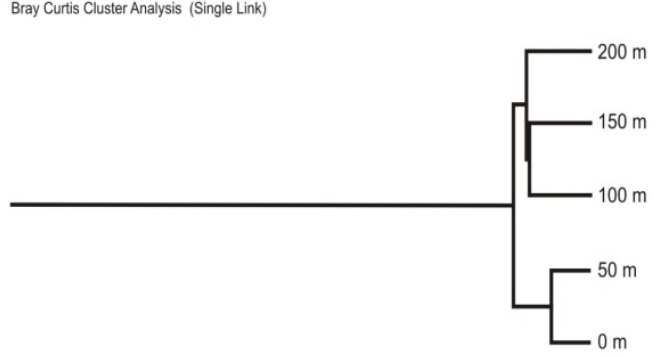
$\%$ similiarity
50
A.

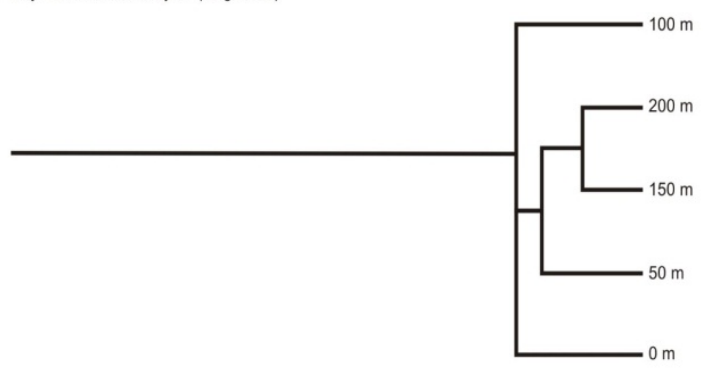

Figure 3. Species composition similarity between the distance from the forest in Strawberry (A) and Tomato (B) using Bray-Curtis similarity index.

with increasing distance from forest edge. This result is in agreement with that of Ricketts et al. (2008), who reported that the native pollinator visitation rate drops to $50 \%$ of the maximum at a location $668 \mathrm{~m}$ from natural habitat, and is consistent with previous reports of the effect of forest on bee visits and pollination services (De Marco $\&$ Coelho 2004; Chacoff \& Aizen 2006).

These results suggest that forest edges are important sources of pollinators, likely because they provide "partial habitats" ( Holland \& Fahrig, 2000), such as mating, foraging, nesting, and nesting materials sites, which bees need to complete their life cycle (Bailey et al., 2014). Klein et al. (2003), in their study of coffee pollination in agroforestry systems at Lore Lindu (Central Sulawesi), verified that the number of social bee species diminished with the distance between fragments. De Marco \& Coelho (2004) verified that cultivation near forest fragments (distance $<1 \mathrm{~km}$ ) results in $14.6 \%$ greater production when compared to distant systems. Ricketts et al., (2008) reported a greater increase, $20 \%$, in Costa Rica. This effect of distance from semi-natural habitats suggests that variables related to landscape ecology, such as the permeability of the matrix to the dispersion of pollinators, may be essential
(Jauker et al., 2009). Forest edges could provide one or more important partial habitats for diverse bee species in agricultural landscapes, in particular when associated with flowering agricultural crops (Le Feon et al., 2011). Species composition according to the distance from the forest edge was evaluated using a single linkage cluster analysis based on Bray-Curtis similarity. The species composition at forest edges exhibited the highest similarity $(92.8 \%$ in strawberry plots and $79.7 \%$ in tomato plots, respectively) at the closest distance $(50 \mathrm{~m})$ and lowest similarity $(76.3 \%$ in strawberry plots and $58.8 \%$ in tomato plots) at the farthest distance $(200 \mathrm{~m})$ from forest edges in plots of both crops. (Figure 3)

These research findings may be due to differences in foraging distance among wild bee taxa. Foraging distance has been shown to increase the body size of bees (Greenleaf et al., 2007). Foraging distance, therefore, determines the spatial scale at which wild bees can provide pollination services to crops (Greenleaf \&Kremen 2006). Many wild bees that pollinate crops nest in natural habitats and forage on crops within their daily travel distance (Schulke \& Waser, 2001). Foraging bees are likely to fly short distances, recent investigations predicted maximum fora- 
ging distances of 100-200 $\mathrm{m}$ for small bee species and up to $1100 \mathrm{~m}$ for very large species based on mainly indirect methods (Zurbuchen et al., 2010) and change directions between successive visits to high-reward patches and fly longer distances in the same direction to low-reward patches (Ne'man et al., 2006). These studies suggest that forest edges are likely to be a source of pollinators of various crops. Indeed, forest edges exhibit a complex vegetation structure and undisturbed soil, offering shelter for bees and a wide range of nesting sites for both cavity and ground-nesting bees (Artz \& Waddington, 2006). In addition, they provide a diversity of flowering wild plants throughout the bees' activity period (Margrach et al., 2013). Widhiono \& Sudiana (2015) found that forest edges in this study area harbor diverse flowering wild plant species. Several studies have shown the importance of natural or semi-natural habitats for sustaining pollinator populations or pollination services close to fruit crops (Chacoff \& Aizen, 2006; Ricketts et al., 2008; Carvalheiro et al., 2010). Other studies have reported a negative impact of distance on forests on pollination services or bee abundance and richness in tropical ecosystems (De Marco \& Coelho 2004; Chacoff et al., 2008). Finally, these studies also suggest that the pollination of strawberry and tomato crops could be negatively affected by being situated too far from the forest edge.

\section{CONCLUSION}

Forest edge habitats are important for enhancing pollinator diversity in agricultural landscapes. They harbor diverse wild bee communities and can be considered classical source habitats. Dispersal from these forest edge habitats into the agricultural area, however, is strongly affected by the distance from the forest edge.

\section{ACKNOWLEDGEMENTS}

We are thankful to Yulia Arnitasari, and Farda Komarudin who have helped data collection and encouraged this work from the beginning. This research was a part of main research that founded by Jenderal Soedirman University. We are also thankful to authorities of Institute of Research and Community Services, Jenderal Soedirman University for support.

\section{REFERENCES}

Artz, D. R. \& Waddington, K. D. (2006). The effects of neighbouring tree islands on pollinator density and diversity, and on pollination of a wet prairiespecies, Asclepias lanceolata (Apocynaceae). Journal of Ecology, 94(3), 597-608

Bailey, S., Requier, F., Nusillard, B., Roberts, S. P., Potts, S. G., \& Bouget, C. (2014). Distance from forest edge affects bee pollinators in oilseed rape fields. Ecology and evolution, 4(4), 370380.

Chacoff, N. P., \& Aizen, M. A. (2006). Edge effects on flower-visiting insects in grapefruit plantations bordering premontane subtropical forest. Journal of Applied Ecology, 43(1), 18-27. Chacoff, N. P., Aizen, M. A., \& Aschero, V. (2008). Proximity to forest edge does not affect crop production despite pollen limitation. Proceedings of the Royal Society of London B: Biological Sciences, 275(1637), 907-913.

Carvalheiro, L. G., Seymour, C. L., Veldtman, R., \& Nicolson, S. W. (2010). Pollination services decline with distance from natural habitat even in biodiversity-rich areas. Journal of Applied Ecology, 47(4), 810-820.

Cresswell, J. E. (1999). The influence of nectar and pollen availability on pollen transfer by individual flowers of oil-seed rape (Brassica napus) when pollinated by bumblebees (Bombus lapidarius). Journal of Ecology, 87(4), 670-677.

De Marco Jr, P., \& Coelho, F. M. (2004). Services performed by the ecosystem: forest remnants influence agricultural cultures' pollination and production. Biodiversity \& Conservation, 13(7), 1245-1255.

Greenleaf, S. S., \& Kremen, C. (2006). Wild bee species increase tomato production and respond differently to surrounding land use in Northern California. Biological Conservation, 133(1), 8187.

Greenleaf, S. S., Williams, N. M., Winfree, R., \& Kremen, C. (2007). Bee foraging ranges and their relationship to body size. Oecologia, 153(3), 589596.

Harter, B., Leistikow, C., Wilms, W., Truylio, B., \& Engels, W. (2002). Bees collecting pollen from flowers with poricidal anthers in a south Brazilian Araucaria forest: a community study. Journal of Apicultural Research, 41(1-2), 9-16.

Holland, J., \& Fahrig, L. (2000). Effect of woody borders on insect density and diversity in crop fields: a landscape-scale analysis. Agriculture, ecosystems \& environment, 78(2), 115-122.

Jauker, F., Diekötter, T., Schwarzbach, F., \& Wolters, V. (2009). Pollinator dispersal in an agricultural matrix: opposing responses of wild bees and hoverflies to landscape structure and distance from main habitat. Landscape Ecology, 24(4), 547-555.

Klein, A. M., Steffan-Dewenter, I., \& Tscharntke, T. (2003). Fruit set of highland coffee increases with the diversity of pollinating bees. Proceedings of the Royal Society of London B: Biological Sciences, 270(1518), 955-961.

Le Féon, V., Burel, F., Chifflet, R., Henry, M., Ricroch, 
A., Vaissière, B. E., \& Baudry, J. (2013). Solitary bee abundance and species richness in dynamic agricultural landscapes. Agriculture, Ecosystems \& Environment, 166, 94-101.

Magrach, A., Santamaría, L., \& Larrinaga, A. R. (2013). Forest edges show contrasting effects on an austral mistletoe due to differences in pollination and seed dispersal. Journal of Ecology, 101(3), 713-721.

Magurran, A. E. (2013). Measuring biological diversity. New Jersey: John Wiley \& Sons.

McAleece, N., Lambshead, P. J. D., Paterson, G. L. J., \& Gage, J. D. (1997). Biodiversity Pro. The Natural History Museum, London.

Gotelli, N. J., Chao, A., \& Levin, S. (2013). Measuring and estimating species richness, species diversity, and biotic similarity from sampling data. Encyclopedia of biodiversity, 5, 195-211.

Ne'eman, G., Shavit, O., Shaltiel, L., \& Shmida, A. (2006). Foraging by male and female solitary bees with implications for pollination. Journal of Insect Behavior, 19(3), 383-401.

Perhutani. 2000. Rencana Pengelolaan Pelestarian Hutan,
Kelas hutan Damar. Perencanaan Hutan II, Yogyakarta.

Ricketts, T. H., Regetz, J., Steffan-Dewenter, I., Cunningham, S. A., Kremen, C., Bogdanski, A., ... \& Morandin, L. A. (2008). Landscape effects on crop pollination services: are there general patterns?. Ecology letters, 11(5), 499-515.

Schulke, B., \& Waser, N. M. (2001). Long-distance pollinator flights and pollen dispersal between populations of Delphinium nuttallianum. Oecologia, 127(2), 239-245.

Teppner, H. (2005). Pollinators of tomato, Solanum lycopersicum (Solanaceae), in central Europe. Phyton, 45(2), 217-235.

Widhiono, I. \& Sudiana, E. (2015). Peran tumbuhan liar dalam konservasi keragaman serangga penyerbuk Ordo Hymenoptera. Pros Sem Nas Masy Biodiv Indon. Vol 1, No 7, 1586-1590.

Zurbuchen, A., Landert, L., Klaiber, J., Müller, A., Hein, S., \& Dorn, S. (2010). Maximum foraging ranges in solitary bees: only few individuals have the capability to cover long foraging distances. Biological Conservation, 143(3), 669-676. 